\title{
Legal Politics of Electric Vehicle Development in Indonesia
}

\author{
Moch. Syafrudin Dwi Sapto Laxamanahady ${ }^{1 *}$ and Sunny Ummul Firdaus ${ }^{2}$ \\ ${ }^{1}$ Institute of Technology Management and Entrepreneurship, Universiti Teknikal Malaysia Melaka, Malaysia \\ ${ }^{2}$ Center for Democracy and National Security, Universitas Sebelas Maret Surakarta, Indonesia \\ *Corresponding author. Email: mochlaxamana@gmail.com
}

\begin{abstract}
The present article entitled "Legal Politics of Electric Vehicle Development in Indonesia" elaborates the issue of air pollution escalation in Indonesia due to the increasing amount of motor vehicle exhaust emission. This issue becomes urgent for air pollution plays a significant role to people's health with the fact that various premature deaths happen because of air pollution. In addition, the majority of world citizen are in places where air quality is far below the good quality standard. The existence of electric vehicle is the option which can be utilized as an attempt to alleviate emissions in the air. The researcher employs socio-legal law method in this research. The results confirm that there is a study on regulation and policy that are currently being implemented, a policy recommendation that can be applied by the government to enforce people's health protection, and an electric vehicle that is suitable with the condition of Indonesia.
\end{abstract}

Keywords: Air pollution, policy, electric vehicle

\section{INTRODUCTION}

Air is the only component that must exist, and its presence must be assured in the environment of all living things, including human, animals and plants. As the component of environment, air quality must be conserved and enhanced so that it is able to support living things live optimally.[1] According to Government Regulation Number 22/2021, ambient air is the free air on earth' troposphere existing in the Indonesian Republic jurisdiction zone which is needed and affects human's health, living things, and other living environments.

Fardiaz (1992) defines air as the combination of gases surrounding the earth. Air consists of $78 \%$ nitrogen, $21.94 \%$ oxygen, $0.93 \%$ argon, $0.032 \%$ carbon dioxide and the other noble gases on atmosphere.[2] Clean and health air is definitely the most vital of human's need as it affects human' health. Clean air is unpolluted air which is free from various health-dangerous substances, such as carbon dioxide, carbon monoxide, dust, and others.

There must a standard for the existence of healthy and clean air as part of ensuring the existence of air in an area. According to British Columbia Air Quality (2016) air quality means the state of the air around us which refers to clean or polluted air. Air quality is generally assessed from air concentration parameters that are higher or lower than the National Ambient Air Quality Standard.[3] Article 1 point 43 of PP No. 22/2021 states that air quality is air condition at a certain time and place measured and/or tested based on certain parameters and certain methods based on the provisions of laws and regulations.

Table 1. National Ambient Air Quality Standard

\begin{tabular}{|c|c|c|c|}
\hline No. & Parameters & $\begin{array}{c}\text { Time of } \\
\text { Measurement }\end{array}$ & $\begin{array}{c}\text { Quality } \\
\text { Standard }\end{array}$ \\
\hline \multirow{3}{*}{1.} & \multirow{3}{*}{$\begin{array}{c}\text { Sulfur } \\
\text { dioxide }\left(\mathrm{SO}_{2}\right)\end{array}$} & 1 hour & $150 \mu \mathrm{g} / \mathrm{m}^{3}$ \\
\hline & & 24 hours & $75 \mu \mathrm{g} / \mathrm{m}^{3}$ \\
\hline & & 1 year & $45 \mu \mathrm{g} / \mathrm{m}^{3}$ \\
\hline \multirow{2}{*}{2.} & \multirow{2}{*}{$\begin{array}{c}\text { Carbon } \\
\text { Monoxide } \\
(\mathrm{CO})\end{array}$} & 1 hour & $10000 \mu \mathrm{g} / \mathrm{m}^{3}$ \\
\hline & & 8 hours & $4000 \mu \mathrm{g} / \mathrm{m}^{3}$ \\
\hline \multirow{3}{*}{3.} & \multirow{3}{*}{$\begin{array}{c}\text { Nitrogen } \\
\text { Dioxide }\left(\mathrm{No}_{2}\right)\end{array}$} & 1 hour & $200 \mu \mathrm{g} / \mathrm{m}^{3}$ \\
\hline & & 24 hours & $65 \mu \mathrm{g} / \mathrm{m}^{3}$ \\
\hline & & 1 year & $50 \mu \mathrm{g} / \mathrm{m}^{3}$ \\
\hline 4. & & 1 hour & $150 \mu \mathrm{g} / \mathrm{m}^{3}$ \\
\hline
\end{tabular}




\begin{tabular}{|c|c|c|c|}
\hline \multirow{2}{*}{\multicolumn{2}{|c|}{$\begin{array}{c}\text { Photochemic } \\
\text { al Oxidant } \\
\left(\mathrm{O}_{\mathrm{x}}\right) \text { as Ozone } \\
\left(\mathrm{O}_{3}\right)\end{array}$}} & 8 hours & $100 \mu \mathrm{g} / \mathrm{m}^{3}$ \\
\hline & & 1 year & $35 \mu \mathrm{g} / \mathrm{m}^{3}$ \\
\hline 5. & $\begin{array}{c}\text { Non-methane } \\
\text { Hydrocarbons } \\
\text { (NMHC) }\end{array}$ & 3 hours & $160 \mu \mathrm{g} / \mathrm{m}^{3}$ \\
\hline \multirow{5}{*}{6.} & $\begin{array}{c}\text { Dust } \\
\text { Particulate < } \\
100 \mu \mathrm{g} \text { (TSP) }\end{array}$ & 24 hours & $230 \mu \mathrm{g} / \mathrm{m}^{3}$ \\
\hline & \multirow{2}{*}{$\begin{array}{c}\text { Dust } \\
\text { Particulate < } \\
10 \mu \mathrm{g}\left(\mathrm{PM}_{10}\right)\end{array}$} & 24 hours & $75 \mu \mathrm{g} / \mathrm{m}^{3}$ \\
\hline & & 1 year & $40 \mu \mathrm{g} / \mathrm{m}^{3}$ \\
\hline & \multirow{2}{*}{$\begin{array}{c}\text { Dust } \\
\text { Particulate < } \\
2,5 \mu \mathrm{g}\left(\mathrm{PM}_{2,5}\right)\end{array}$} & 24 hours & $55 \mu \mathrm{g} / \mathrm{m}^{3}$ \\
\hline & & 1 year & $15 \mu \mathrm{g} / \mathrm{m}^{3}$ \\
\hline 7. & Lead $(\mathrm{Pb})$ & 24 hours & $2 \mu \mathrm{g} / \mathrm{m}^{3}$ \\
\hline
\end{tabular}

The quality standards are the criteria for measuring the air quality of an area as well as the air pollutant standard index (ISPU) which provides a depiction of ambient air quality conditions at a certain location and time based on the impact on human health, aesthetic values, and other living things. Meanwhile, air pollution is the entry or inclusion of substances, energy, or other components into the air by human activities, so that it exceeds the air quality standards that have been set.[4] The case of air pollution continues to increase in line with the development of modern life. As the number of humans increases, there will be an increase in waste that pollutes the air, so that it will increase pollutant substances and will correlate with increasing number of people who experience disorders and diseases due to air pollution.[5]

Air pollutant particle increases globally where this problem as effect of modernization and industrialization is being faced by all country. In $2017,92 \%$ of the world's population still lived in areas where PM2.5 exceeds the WHO guideline for healthy air; 54\% still lived in areas exceeding the WHO's least-stringent interim target, often by substantial margin [6]. In 2019, 99\% of the world population was living in places where the WHO air quality guidelines levels were not met [7]. This shows that the level of air pollutant globally facing serious condition and worrying. Indonesia as a country with big population in the world also experiences this problem.

Air condition in Indonesia is getting worse in the last two decades. Moreover, based on the observation by AQLI, 91\% Indonesians live in area with the above safe air pollutant level that is recommended by WHO.[8] This condition is getting worse especially in the big city which has high mobility and industry.
The increase of this air pollution absolutely is caused by many factors that some of them are the increase of industrialization rapidly in big city, the use of fossil which causing pollution, and the modernizing the city which cause limited source of oxygen because of land use conversion then having no forest city or open green area in the city.

Ministry of transportation Indonesia said that $60 \%$ pollution occurs because of the use of bike and car that used fuel oil or low octane fuel oil.[9] According to Statistics Indonesia (BPS) and Indonesian Motor Bike Industry Association (AISI), per January 2021, motor bikes in Indonesia reach 147,75 million units. Meanwhile cars reach 24,6 million units.

The increase of the use of motor vehicle every year certainly gives impact toward the quality of air around. The problem of air pollution continues and causes domino effect to some aspects, such as decreasing public health if the air pollution keeps going on and causes premature death. Other than that, the use of motor vehicle also needs fossil fuel that certainly will exploit nonrenewable resources. The new innovation in prevention and control of air pollution certainly becomes one of thing that is needed by the modern society. Moreover, this cannot be stopped, but still can be held by preparing the newer innovation that can give benefit and protection for environment and human living. Based on the background, The author will discuss about the government of Indonesia's policy about electric vehicle and ideal policy that must be applied about electric vehicle to maintain public health.

\section{DISCUSSION}

\subsection{Indonesian government currently regulated policies on the use of vehicle}

The increasingly high mobility of modern society as the demands of modernization, where effectiveness and efficiency are upheld, causes an elevation in the use of private vehicles which is getting higher. The inability of public transportation modes to accommodate the increasing use of private vehicles further complicates the problem of air pollution and the use of fuel as well as national exhaust gas emissions.

According to Soedomo (2001), air pollution caused by motor vehicles is $70-80 \%$, while air pollution due to industry and others is only $20-30 \%$. This global problem, which is also a national responsibility, has implications for the government that the government certainly provides various efforts and policies to overcome this problem. Regulations and policies will certainly become a package that the government will immediately issue 
to prevent complex problems on air pollution which is increasingly heading in a very serious direction. The regulations and policies currently implemented by Indonesia include:

\section{a. Government Regulation Number 73/2019}

The regulations pertaining to taxable goods classified as luxury in the form of motor vehicles subject to sales tax on luxury goods is one of the basis of government policies in encouraging the use of energy-efficient and environmentally friendly vehicles. It regulates the imposition of taxes on luxury vehicles transporting people based on the ability to transport people and the capacity of the available cylinder contents.

Vehicles with a capacity of less than 10 people are subject to a $15 \%-70 \%$ tax on both motor and electric vehicles. Meanwhile, vehicles with the ability to transport more than 10 people are subject to a $15 \%-30 \%$ taxes for motor and electric vehicles.

Moreover, the goods subject to tax are low carbon emission four-wheeled motor vehicles which are subject to a sales tax of $15 \%$ with a tax base of $20 \%$ of the selling price. Meanwhile, vehicles with full hybrid and mild hybrid technology are subject to a $15 \%$ tax with an imposition of $131 / 3 \%$ to $80 \%$ of the selling price. Four-wheeled motor vehicles using plug-in hybrid electric vehicles, battery electric vehicles or full cell electric vehicles are subject to a tax of $15 \%$ with imposed on a tax base of $0 \%$ of the selling price.

\section{b. Government Regulation Number 55/2019}

The regulations in reference to the acceleration of the battery-based electric motor vehicle program for road transportation are also a strategic policy issued by the government to encourage accelerated implementation. It regulates the acceleration of the development of the electric motor vehicle industry (MVI) through its battery powered activities. This industrial activity includes the research, development, and innovation stages of industrial technology as well as the stages of assembling the MVI. In addition, it also regulates the control of the use of fossil fuel vehicles as one of the migration strategies for use. Furthermore, the government also stipulates the existence of incentives both fiscal and non-fiscal, providing electricity charging infrastructure, setting electricity tariffs, determining MVI standards that are suitable for use as road transportation and regulations in relation to environmental protection. c. Regulation of the Minister of Energy and Mineral Resources Number 13/2020

The regulation pertaining to the provision of electric charging infrastructure for battery-based electric motor vehicles is one of the government's assurances for the use of electric vehicles in Indonesia. The infrastructure that is regulated is the existence of an electric power supply, a current, voltage and communication control system as well as a battery exchange facility. The parties that are allowed to provide this infrastructure are those who have a business license for providing electricity (IUPTL) and a business license for electricity support services (IUJPTL) with the supervision of the Minister of energy and mineral resources and state electricity company. Meanwhile, this rule also regulates the set tariffs, electricity safety, management coordination and administrative sanctions that can be applied to non-compliance with implementation.

\section{d. Regulation of the Ministry of Transportation Number PM 45/2020}

There is regulation about specific vehicle using electric drive to make sure the performance and safety of the use of specific vehicle. The regulated vehicles are electric scooter, electric bike, hover board, unicycle, and toy scooter. This regulation gives knowledge and suggestion for the user to obey the technical use of specific vehicle in public or specific road and about the requirement for authorized people or bureau who rents the specific electric vehicle.

\section{e. Regulation of Minister of Home Affairs Number $8 / 2020$}

The regulations about the basic calculation for the imposition of motor vehicle taxes and title transfer tax for motor vehicles in 2020 become the base for the imposition of tax policies on motor vehicles which are generally in effect today where this regulation also becomes the base for the imposition of regional taxes and levy for region.

This regulation has not accommodated rigidly the existence of electric motor vehicle as a part alone, but this accommodation is based on the analogy of vehicles that have the same type as car, motorcycle and so on. As in this regulation, it is regulated about the existence of a standard for calculating taxes based on the type and selling value of motor vehicle both for land, water, and heavy equipment vehicles. 


\section{f. Regulation of Minister of industry Number $27 / 2020$}

This regulation on specification, development roadmap and provision for calculating the value of domestic components for battery-based electric motor vehicle is one of the regulations that regulate rigidly the implementation of the procurement of electric motor vehicles starting from planning, manufacturing to the provision for calculating the component that must be provided.

This regulation also regulates the roadmap for the development of battery-powered electric motor vehicle industry in 2020-2030 in coordination with ministries/institution, local governments, industrial companies, university and research and development institution. Other than that, there is also a regulation about the level of battery-based domestic component which in its operation will be supervised and evaluated by the General Director which will be reported to the Minister.

\section{g. Regulation of Minister of Industry Number $28 / 2020$}

A battery-based electric motor vehicle in a complete decomposed state and an incomplete decomposed state is a follow-up regulation on the existence of presidential regulation Number $55 / 2019$

This regulation accommodates the implementation of electric motor vehicles based on completely knock down (CKD) batteries and based on incompletely knock down (IKD) batteries in terms of determining the used components, companies that will be involved in the procurement and manufacturing processes that will be carried out. In addition, this regulation also regulates the implementation of the importation of electric motor vehicle by submitting a letter of approval to the general director through SIINas as well as there is reporting and monitoring system that will be carried out on the activities of the electric motor vehicle industry company.

Various regulations and policies that have been implemented when indicate that the Indonesian government gives guarantees for the procurement of electric motor vehicles as part of transportation modernization. Other than that, the existence of this regulation has its own implications for the society to be able to participate in the procurement of electric motor vehicles, both directly involved parties such as academics, researchers, practitioners, students and so on in the manufacturing of electric motor vehicles.

Regulations on policies that have been regulated now have also been sustainable, which a regulation must not have conflict with each other both horizontally and vertically as part of an ideal legal guarantee. This is also seen from the regulation on the procurement of electric motor vehicles, tax regulations for these vehicles, providing incentives for procurement workers, regulations on certain electric vehicles, as well as regulations on where to charge electric vehicle battery.

\subsection{Ideal policy that is applied on electric vehicle to increase public health}

Electric vehicle becomes one of the solutions for air pollution, which is currently increasing in a serious direction where diseases that caused by air pollution including skin cancer (melanoma), lung cancer, angina pectoris and atherosclerosis-purifier. Besides, air pollution also causes bronchitis and emphysema where $\mathrm{SO} 2$ gas and benzopyrene can weaken the movement of vibrating hair in the throat tract and can stimulate mucus secretion in the thickening tracts of the lungs.[10] The worst effect is asphyxia or suffocation caused by $\mathrm{CO}$ gas which is highly reactive to $\mathrm{Hb}$ in the blood with an affinity of 240 greater than its affinity for oxygen. Because $\mathrm{Hb}$ in the blood cannot longer function to absorb and carry oxygen, so the body will suffer from a lack of oxygen.[11]

Hypertension also becomes one of disease that is prone to emerge due to high air pollution, where every five micrograms per cubic meter $(5 \mathrm{~g} / \mathrm{m} 3) \mathrm{PM}$ 2.5 the risk of hypertension increases by 22 percent for people living in high-polluted areas than in minimal pollution area.[12]

This causes the premature death rate due to pollution. Throughout 2020, this has caused potential economic losses reaching 56.5 billion US dollars and resulted in premature death of around 98,000 people worldwide.[13] Then, the premature death rate due to air pollution in Indonesia since January 1, 2020 is estimated to reach more than 9,000 people. Early death in Jakarta is estimated at 6,100 people, in Surabaya 1,700 people, in Denpasar 410 people, and in Bandung 1,400 people.[14]

The electric motor vehicle is a new hope to reduce the health impacts that must be borne by the global community, where air pollution will certainly give a domino impact on various aspects of life. In terms of energy use, electric car is also more profitable with an efficiency range of $90 \%$. The efficiency factor at the power plant to the user is around $25-30 \%$, so the total energy efficiency in electric cars is between 22.5-27\%.[15] This figure shows that electric vehicles have higher efficiency and better than conventional combustion vehicles.[16]

The acceleration of the procurement and massive of the electric vehicles in Indonesia becomes an urgency itself to overcome the problem of air 
pollution and to achieve public health. The various policies that have been regulated at this time have provided guarantees for the existence of electric vehicles in Indonesian regulation, but there are several things that need to be further regulated to encourage the acceleration of the procurement of electric vehicle as well as a means of achieving public health related to air quality. There are several regulations or policies that need to be implemented by the government, including:

\section{a. Policy on electric vehicle resource}

To achieve a healthy air quality, the procurement of electric vehicles needs to be given policies and regulations on the use of resources through nonfossil materials. Furthermore, the current various electric vehicles are not perfect and still have exhaust components. This has direct implications for the resulting exhaust emissions. A 2014 study published in the journal proceedings of the national academy of sciences stated that metal mining is still needed to generate the electricity needed to power it and compared the average emissions of that electric vehicle with gas-powered vehicle.

The team found that when electric vehicles are charged with coal-fired electricity, they are worse for the environment than conventional gasolinefueled car.[17] This is what needs to be further regulated to solve the use of non-renewable energy sources in procurement and implementation of electric vehicles. The essence of environmental protection and reducing exhaust emissions is certainly an important thing that must be achieved. Electric vehicles should use battery resources that are charged using renewable energy sources such as regulation of the use of solar power plants, hydropower, and wind power and so on. Therefore, the guarantees through policies or regulations can be immediately launched to prevent an increase in air pollution that is happening now.

\section{b. Regulations on International Cooperation}

The transportation modernization activity in the form of electric vehicles is certainly inseparable from the global influence in its implementation. Until now, Indonesia has not given policy or regulation that accommodates the duties and responsibilities of the state as the most important part of this plan.

This is seen in the absence of a policy on the state responsibility in implementing international cooperation in the procurement of electric vehicles. If it is investigated, the existing regulation only provides guarantees to companies or the society if they wish to conduct Cooperation or purchase components abroad.
This should become one of the maximum efforts to establish cooperation or government relations with other countries in terms of technology transfer, support, and assistance in the procurement of electric vehicles and so on that can boost the acceleration of the procurement of electric vehicles.

Technology transfer becomes the most important thing to optimize the activities of the electric motor vehicle industry and to make efficient funds and resources that have been allocated to the procurement project. Where this policy can also be a driving force for increasing domestic capacity to produce electric motor vehicle components themselves and reduce sales prices due to component imports.

\section{c. An optimum electric vehicle incentive regulation}

Today's regulations on incentive given to the procurement and production of electric vehicles have been issued by the government, however, there are several problems that are faced related to the existence of electric vehicle components that are subject to high incentive taxes. This directly implicates for the increase of very high price of electric vehicles in Indonesia. The Research Director of the Institute for Development of Economics and Finance (INDEF) stated that the ideal price of an electric car is around IDR 300-400 million. That is why numerous incentives are needed to reduce the price of electric cars which are currently above IDR 600 million.[18].

A pressure and changes to the tax incentive system applied in the current rules and regulations need to be implemented. This is done as a response to the selling price of electric vehicles which is still too high than the Indonesian market price which causes people do not want to buy electric vehicles. Furthermore, local-made electric vehicles are also experiencing the same thing related to the high price of batteries which are currently still imported, and Indonesia has not been able to produce them by themselves. Besides, there is a need for a policy of developing a Public Electric Vehicle Charging Station (SPKLU) throughout Indonesia.

These policies should be needed to accelerate the procurement of electric vehicles to push the acceleration of the transportation transfer to an electricity base to reduce the increase in exhaust emissions that are dangerous to the environment and human life.

\section{CONCLUSION}

Motor vehicle exhaust emission now contributes greatly in creating air pollution globally or nationally where this air pollution also causes declining public health condition to a dangerous 
level. Especially with the development of mobilization, modernization and industrialization that are increasingly being done. This is what encourages electric vehicles as the main solution to prevent an increase in air pollution.

The current various policies and regulations is necessary to accommodate all society needs on the environment and healthy air quality. The ideal policies that need to be further regulated to push public health are policy on electric vehicle resources, policy on international cooperation, and optimal regulation of electric vehicle incentives.

\section{REFERENCES}

[1] S. Nugroho, Analisis Kualitas Udara di Daerah Istimewa Yogyakarta. Yogyakarta, 2009.

[2] W. Wardana, Dampak Pencemaran Lingkungan. Yogyakarta: Andi, 2001.

[3] U. F. et al Rizi D, “ANALISIS DAMPAK DITERAPKANNYA KEBIJAKAN WORKING FROM HOME SAAT PANDEMI COVID-19 TERHADAP KONDISI KUALITAS UDARA DI JAKARTA," $J$. Meteorol. Klimatologi dan Geofis., vol. 6, no. 3, p. 7, 2019.

[4] E. . Waluyo, "Kajian Tingkat Pencemaran Sulfur Dioksida Dari Industri Di Beberapa Daerah Di Indonesia," Ber. Dirgant., vol. 12, no. 4, pp. 132-137, 2011.

[5] R. . Corbitt, Air Pollution in Standard Handbook of Environmental Engineering. New York: McGraw-Hill, 2004.

[6] Health Effect Institute, "State Of Global Fair: A Special Report On Global Exposure To Air Pollution And Its Disease Burden," Boston, 2019.

[7] World Health Organization, "Ambient (outdoor) air pollution," Who.int, 2021. https://www.who.int/news-room/factsheets/detail/ambient-(outdoor)-air-qualityand-health (accessed Sep. 24, 2021).

[8] H. D. Situmorang, "Kualitas Udara di Indonesia Terus Memburuk," Berita Satu, 2021.

https://www.beritasatu.com/nasional/783001/k ualitas-udara-di-indonesia-terus-memburuk (accessed Sep. 25, 2021).

[9] V. N. Setiawan, "Kendaraan Bermotor Sumbang 60\% Polusi, Menhub Dorong Mobil Listrik," Katadata, 2020. https://katadata.co.id/sortatobing/ekonomihijau/5fd331c7eba8f/kendaraan-bermotor-
There needs cooperation between the government as a regulator, the society, and electric vehicle companies in achieving an optimal electric vehicle to reduce air pollution. This synergy will certainly be the most important point in creating the effective use of electric vehicles in Indonesia.

\section{AUTHOR'S CONTRIBUTIONS}

In creating this article, all authors contribute to the study of law on various literature, sociological conditions of the state, and comparative studies with the policies of other countries. So that all authors contribute actively to the preparation of this article.

sumbang-60-polusi-menhub-dorong-mobillistrik (accessed Sep. 25, 2021).

[10] S. . Owen, Natural Resource Conservation : An Ecological Approach. New York: McMillan Publish, 1980.

[11] P. . Eckholm, Masalah Kesehatan : Lingkungan Sebagai Sumber Penyakit. Jakarta: PT. Gramedia, 1983.

[12] S. Aryanti, "DAMPAK PENCEMARAN UDARA (POLUSI UDARA) TERHADAP PENYAKIT HIPERTENSI," Kementerian Kesehatan, 2019.

http://p2ptm.kemkes.go.id/kegiatanp2ptm/dki-jakarta/dampak-pencemaran-udarapolusi-udara-terhadap-penyakit-hipertensi (accessed Sep. 26, 2021)

[13] BensinKita, "Dampak Polusi Udara 2020: Kematian Dini Dunia Capai 98.000 Jiwa, di Indonesia Capai 9.000 Jiwa," bensinkita.com, 2020. https://bensinkita.com/dampak-polusiudara-2020-kematian-dini-dunia-capai-98000-jiwa-di-indonesia-capai-9-000-jiwa/ (accessed Sep. 26, 2021).

[14] Kompas, "Polusi Udara Tahun 2020 Tewaskan Hampir 100.000 Orang di Dunia," Kompas.com, 2020.

https://www.kompas.com/sains/read/2020/07/ 14/080400623/polusi-udara-tahun-2020tewaskan-hampir-100000-orang-didunia?page $=$ all $($ accessed Sep. 25, 2021).

[15] C. Huang et al., "Clinical features of patients infected with 2019 novel coronavirus in Wuhan, China," Lancet, vol. 395, no. 10223, p. 497, Feb. 2020, doi: 10.1016/S01406736(20)30183-5.

[16] E. Liun, "Dampak Peralihan Massal Transportasi Jalan Raya ke Mobil Listrik," $J$. Pengemb. energi Nukl., vol. 19, no. 2, p. 118, 2018. 
[17] D. Nuraini, "Benarkah Kendaraan Listrik Lebih Baik Untuk Bumi? Ini Kata Ahli," Bisnis.com, 2021.

https://teknologi.bisnis.com/read/20210301/84 /1362220/benarkah-kendaraan-listrik-lebihbaik-untuk-bumi-ini-kata-ahli (accessed Sep. 26, 2021).
[18] I. Daily, "Mobil Listrik Butuh Tambahan Insentif," Kemenperin.go.id, 2021. https://kemenperin.go.id/artikel/22409/MobilListrik-Butuh-Tambahan-Insentif (accessed Sep. 26, 2021). 